\title{
CAUSES AND CONSEQUENCES OF DEPOPULATION IN THE MUNICIPALITY OF KURŠUMLIJA
}

\author{
MILEN VASILJEVIĆ ${ }^{1}$, DANIJELA VUKOIČIĆ ${ }^{1 *}$, ALEKSANDAR VALJAREVIĆ ${ }^{1}$
}

${ }^{1}$ Faculty of Natural Sciences and Mathematics, University of Priština, Kosovska Mitrovica, Serbia

\begin{abstract}
The municipality of Kuršumlija is located in the South of Serbia, encompassing the area of $952 \mathrm{~km}^{2}$. According to the census from 2011, it is inhabited by 19,213 people. During the last decades, the municipality is facing the rapid decrease in the number of inhabitants, caused by natural and social factors. The manuscript analyzes the demographic changes reflected in the migration and structure of population in the period after 1948, along with the beginning of the industrial development, to 2011, when the municipality experienced the crash of economy. The analysis established that the municipality of Kuršumlija became emigrational area, especially after the closure of large industrial facilities which were the pillars of development. The young ones and those able for work were forced to leave their hearths, in search for employment and survival. All the settlements of Kuršumlija were included in the negative demographic processes reflected in the constant decrease of population. Big problem was also the intensity of inhabitants' ageing, and lessening of the percentage of young ones, which points out that the municipality is in the phase of the deepest demographic age. The worrying fact is that the tendency of the population rate decrease in the settlements of Kuršumlija 'municipality is prolonged.
\end{abstract}

Keywords: Demographic changes, Depopulation, Migration, Population, Households.

\section{INTRODUCTION}

Migrations represent voluntary or enforced leaving of the place of permanent residence for a certain period of time (Bakić, 1977). They can be of permanent or temporary character (Vojković, 2007). One of the roughest division is on legal and illegal, i.e. voluntary and enforced (Bakić, 1977). Migrations of population may have positive and negative effects. The positive ones are provision of better life conditions for migrants and their families, whereas the negative ones are total or partial voidance of certain areas and depopulation of the same (Blagojević, 2016). In the last fifty years the number of migrants has been very big and it is constantly increasing. The inhabitants of those parts of the world endangered by war are those who are migrating most often, especially from the area of Middle East, Israel and Syria (Bobić et al., 2014). Europe has been always attracting migrants, thus constantly facing the large inflow of population. According to the United Nations' records, more than 50 million people migrated to Europe in the second half of the $20^{\text {th }}$, and the beginning of the $21^{\text {st }}$ century (Morokvasić, 2013). Those parts of the world to which people mostly migrate suffer enormous demographic changes, which could be both positive and negative. When it comes to its structure, Europe is becoming more and more diverse due to the large inflow of young people. One of the negative consequences of migration is that the population moving in is at the lower level of culture, therefore these differences may cause the crash of a state and its welfare. Member countries of EU are most often those chosen for

\footnotetext{
* Corresponding author: danijela.vukoicic@pr.ac.rs
} GEOGRAPHY, GEOSCIENCE AND ASTRONOMY immigration because of the high life standard and possibility of employment.

In the countries which people emigrated from, negative demographic trends led to the decrease of birth rate, higher mortality rate and the intense ageing of population (Heleniak, 2015).

In the past, Serbia was always an emigrational area with long history and wide territorial dispersion of emigration (Grćić, 2010). The second half of the $20^{\text {th }}$ century was marked by migration and transitory movements on the territory of Serbia as well as in the Balkans in general. In the first half of the $20^{\text {th }}$ century, there were certain demographic changes being caused by the late and intense modernization and urbanization (Rudić, 1978). They brought about the intense migration of the work force on the relation between a country and a city (Maksimović, 1996). The last decade of the $20^{\text {th }}$ century is characterized by economic issues which encompassed all the regions in Serbia, and contributed to the emigration mostly of those able for work, as well as highly qualified people to the countries of Western Europe (Marinović, 1999). According to the Statistical office of the Republic of Serbia, there are 313,411 people currently living abroad for the purpose of temporary work (2011), mostly in Austria and then in Germany and Switzerland. Migrations caused by the political situation occurred at the end of the $20^{\text {th }}$ and the beginning of the $21^{\text {st }}$ century, with the escalation of conflict between Serbians and Albanians in Kosovo and Metohija, which ended with the air attack of NATO against Serbia in March, 1999 (Marinović, 1999). Due to endangered safety, a large number of Kosovo' residents, running from persecution and war, inhabited borderland and central parts of the Republic of Serbia. These internal dispersions have significantly changed the structure of population in the areas they inhabited. One of the negative 
tendencies of migrations in Serbia was the spatial concentration of inhabitants in large urban environments, which caused low fertility rate, thus the intense ageing of the local inhabitants and depopulation (Bobić et al., 2014).

The topic of this research is the analysis of causes and consequences of demographic changes in the settlements of the municipality of Kuršumlija. The task of the research is to point to demographic changes, especially in the structure, which occurred within the period between 1948 and 2011, and which were the result of economic underdevelopment, as well as the analysis of movement and migrations of the overall population, which was conducted based on the statistical data collected from these periods 'census and field research. The results of the research should point to the consequences, which would be the ground for taking the appropriate measures to remove the flaws of SWOT analysis. It is necessary to use the chance given and prevent possible threats.

\section{THEORETICAL PART}

\section{Study area}

The municipality of Kuršumlija is located in southern Serbia, in the Toplica region. It is spread between $42^{\circ} 52^{\prime} 33^{\prime \prime}$ and $43^{\circ} 8^{\prime} 27^{\prime \prime}$ of northern latitude and between $19^{\circ} 09^{\prime} 28^{\prime \prime}$ and $21^{\circ} 16^{\prime} 4^{\prime \prime}$ of eastern longitude (Figure 1).

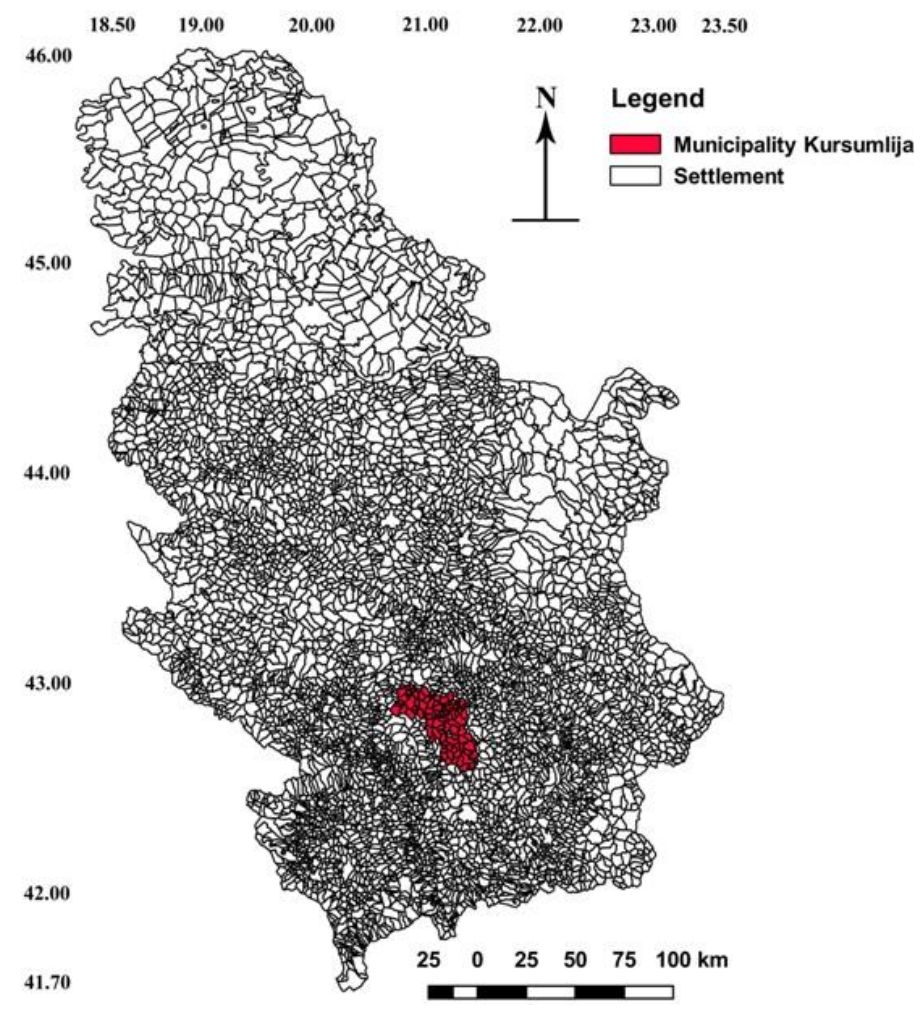

Figure 1. Position of the Municipality of Kuršumlija in the territory of Serbia.

According to its surface $\left(952 \mathrm{~km}^{2}\right)$, the municipality of Kuršumlija belongs to one of the largest municipalities in the
Republic of Serbia. Kuršumlija is the largest municipality in the Toplica region, to which its territory belongs. It spreads between Radan mountain in the East, Majdan mountain and mountain pass Prepolac in the South and Kopaonik in the West. It borders with seven municipalities: in the North the municipality of Blace, in the northeast the municipality of Prokuplje, in the South and southeast with the municipalities of Bojnik and Medveđa, in the South the municipality of Podujevo, in the west the municipality of Leposavić, and in the northwest the municipality of Brus. The administrative center is the city of the same name, Kuršumlija, which spreads on the surface of 1,131 ha of urban territory (Vukoičić, 2014). The municipality of Kuršumlija encompasses 88 settlements according to the records from 2011, with 19,213 inhabitants. The distance of the municipality from Belgrade is $307 \mathrm{~km}$, through Niš, and $266 \mathrm{~km}$ through Kruševac. The distance of the municipality from Priština is $66 \mathrm{~km}$ through Merdare and $62 \mathrm{~km}$ through the mountain pass Prepolac.

\section{EXPERIMENTAL}

\section{Materials and methods}

In the summer of 2018, field researches were conducted in 20 rural settlements on the territory of the municipality of Kuršumlija. Five out of twenty of them are at the very border with Kosovo and Metohija (Trmka, Dabinovac, Mačja Stena, Rastelica and Mrča) (Vukoičić \& Nikolić, 2013). Field researches and questionnaires for 120 inhabitants of different educational level and social status, confirmed the facts stated about the change in the overall number of inhabitants in the settlements of Kuršumlija as well as the prominence of migrations. Based on the same questionnaires, five interviews have been conducted, with people from Kosovo and Metohija. People who finished primary and high school, mostly from the countries, as well as highly educated people working in public facilities, or those currently unemployed, participated in the questioning.

Bad demographic picture is conditioned by the closure of large industrial facilities, which were the pillars of this area's development and the only chance for survival on this territory. In the period between 1948 and 2011, settlements on the territory of the municipality of Kuršumlija are characterized by negative demographic trends, caused by the intense emigration of population from this area (Vukoičić et al., 2011).

The study analyzes the circumstances which cause the massive emigration of population, through questionnaires and statistical analysis. Statistic method processes all the data from the enlisted censuses. Questionnaire data were processed in the statistical programme SPSS 21.

GIS analysis has shown all the settlements in which depopulation is total (with no residents, below 49 residents; from 50 to 199 residents; from 200 to $499 ; 500$ to $999 ; 1,000$ to 1,999 and above 2000 residents). 


\section{NUMERICAL RESULTS}

The results of the research

In the settlements of the municipality of Kuršumlija there are currently 19,213 inhabitants, with the average age of 35.7 years (34.6 for men and 36.8 for women). There are 7,104 households with 2.7 members in average. The municipality of Kuršumlija is mostly inhabited by Serbians (Statistical office of the Republic of Serbia, 2011). After the World War II, according to the data from the conducted censuses, the number and density of population were growing until 1953. In the first census from 1948 in the settlements of Kuršumlija, there were
37, 284 inhabitants out of whom 2,797 were living in the city and 34,489 in other settlements. In the same year, the density of population was 33.9 residents $/ \mathrm{km}^{2}$.

In 1953, the number increased to 39,772 inhabitants out of whom 3,134 were living in the city and 34,487 in the other settlements. In the period between the first two censuses, the number of inhabitants increased for 2,448 or $6,6 \%$ (Table 1). It was accordingly followed by the increase of density of population, which reached its maximum in the same year, which was 41.7 residents $/ \mathrm{km}^{2}$. The highest agrarian density of population was also noted in the same year of census $38.9 / \mathrm{km}^{2}$, after which it was constantly decreasing.

Table 1. Movement of the total number of inhabitants in the settlements of the municipality of Kuršumlija between 1948 -2011.

\begin{tabular}{|ccccccc|}
\hline & \multicolumn{2}{c}{ Total } & \multicolumn{2}{c}{ Urban settlement } & \multicolumn{2}{c|}{ Rural settlements } \\
Year & Number & $\begin{array}{c}\text { Growth / Fall } \\
\text { Index }\end{array}$ & Number & $\begin{array}{c}\text { Growth / Fall } \\
\text { Index }\end{array}$ & Number & Index \\
1948. & 37.284 & $/$ & 2.797 & $/$ & 34.487 & 1 \\
1953. & 39.772 & 106,6 & 3.134 & 112,0 & 36.638 & 90,2 \\
1961. & 36.896 & 92,7 & 3.848 & 122,7 & 33.048 & 73,0 \\
1971. & 31.672 & 85,8 & 7.518 & 195,3 & 24.154 & 69,8 \\
1981. & 27.629 & 87,2 & 10.748 & 142,9 & 16.881 & 64,4 \\
1991. & 23.590 & 85,3 & 12.710 & 118,2 & 10.880 & 71,8 \\
2002. & 21.608 & 91.5 & 13.790 & 108,4 & 7.818 & 75,5 \\
2011. & 19.213 & 88,9 & 13.306 & 96,4 & 5.907 & 7 \\
\hline
\end{tabular}

Source: Census of Population, Households and Flats in 2011, comparative overview, book no. 20, Belgrade, 2014

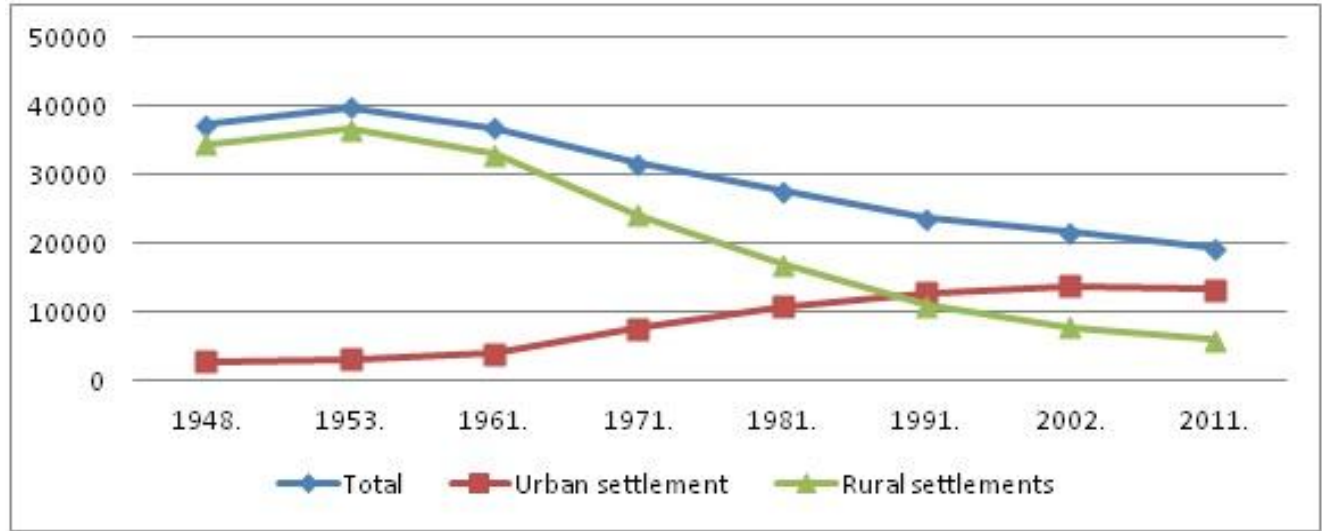

Figure 2. Movement of the total number of inhabitants in the settlements of the municipality of Kuršumlija between 1948 - 2011.

The number of inhabitants in the settlements of the municipality of Kuršumlija has been decreasing constantly in the past decades, which was caused by numerous factors. The only increase was in the period between two censuses, after the World War II, more precisely between 1948 and 1953. Since that period until the census in 2011, the number of inhabitants has decreased for 20,559 residents or $51,65 \%$. According to these data, the settlements from Kuršumlija territory have lost a number of inhabitants greater than the number of those currently living there. The process of depopulation in the municipality of Kuršumlija was not equal in the inter-census periods between
1953 and 2011. In the period between 1953 and 1961 the number decreased for 2,876 people or $7.2 \%$; from 1961 to 1971 for 5,224 or $14.1 \%$; from 1971 to 1981 for $4,043(12,7 \%)$, from 1981 to 1991 for 4, $039(14,6 \%)$, from 1991 to 2002 for $1,982(8,4 \%)$, and from 2002 until 2011 the number of residents decreased for 2, 395 or $11,1 \%$ (Table 1 ).

The same situation stands for the population density, therefore since 1953 until the census in 2011, the number is decreased for $48 \%$. The decrease was mostly visible in rural areas, with the rapid fall of the number of inhabitants, the population density fell as well. The highest population density in 
other settlements was in 1953-36.6 residents $/ \mathrm{km}^{2}$ and the lowest in $2011-6.2$ residents $/ \mathrm{km}^{2}$ (Table 2). The city area marked the increase until 2002 when it reached 1,220.3 residents $/ \mathrm{km}^{2}$, which was the consequence of massive migrations between villages and cities (Table 2). According to the data from 2011, the average population density in Serbia was 92 residents $/ \mathrm{km}^{2}$, in the Toplica region 40,6 residents $/ \mathrm{km}^{2}$, so that the density in the settlements of the municipality of Kuršumlija was smaller than the average density of the county and the Republic.

Tabel 2. Movement of average population density in settlements in the municipality of Kuršumlija st/km².

\begin{tabular}{ccccccccc|}
\hline Year & 1948. & 1953. & 1961. & 1971. & 1981. & 1991. & 2002. & 2011. \\
Total & 33,9 & 41,7 & 38,7 & 33,2 & 29,0 & 24,7 & 22,7 & 20,1 \\
Urban settlement & 247,52 & 277,3 & 340,5 & 665,3 & 951,1 & $1.124,7$ & $1.220,3$ & $1.177,5$ \\
Rural settlement & 36,6 & 38,9 & 35,1 & 25.6 & 17,9 & 11,5 & 8,3 & 6.2 \\
\hline
\end{tabular}

Source: Census of Population, Households and Flats in 2011, comparative overview, book no. 20, Belgrade, 2014

The settlements on the territory of Kuršumlija municipality are mostly of a jagged type, except the city area which is more compact. The settlements mostly belong to the mountain type. Those of a jagged type are located on the slopes of Kopaonik, at the farthest west of the municipality of Kuršumlija, but also on the slopes of Radan mountain, in the east of municipality (Vukoičić et al., 2011). In the period between 1953 and 2011 all the settlements of Kuršumlija municipality underwent the process of redistribution. This led to the constant increase of population in the city, followed by the intense decrease in rural areas. This process also had some positive effects on the unburdening of overpopulated rural areas, especially in the 1960 s, because of the high fertility rate. Emigration of inhabitants was specifically from the villages on the slopes of Kopaonik and Radan.

Tabel 3. Number of inhabitants in the settlements of the municipality of Kuršumlija according to the international classification of settlements according to the census data from 1948 and 2011.

\begin{tabular}{|c|c|c|}
\hline Size groups & 1948. & 2011. \\
\hline to 49 & l & 44 \\
\hline $50-199$ & 20 & 38 \\
\hline $200-499$ & 48 & 4 \\
\hline $500-999$ & 18 & / \\
\hline $1.000-1.999$ & 2 & l \\
\hline 2.000 and more & & \\
\hline
\end{tabular}

According to the data from the table 3 in the periods of census in 1948 and 2011, the number of inhabitants drastically decreased in other settlements. The data from 1948 stated that only two settlements had below than 100 inhabitants-Žalica (92) and Rastelica (82). There were no settlements in the category below 49 inhabitants.

According to the data from 2011 census, there are 44 settlements below 49 inhabitants. In 1948, there were 20 settlements between 50 and 199 inhabitants, and in 2011 there were 38 (Table 3), (Figure 3). In the years that followed the World War II, two settlements had above 1,000 inhabitants Rača with 1,143 and Spance, not very far from Kuršumlija, had 1,054 inhabitants in 1948. These two settlements suffered the greatest decrease in population between the first and the last census. Both of them have extremely good traffic position, which has been their pillar of development for a very long period. In Rača, there was also a unit of the textile factory " 7 juli” from Kuršumlija which was hiring approximately 800 people from Rača and surrounding villages. Unsuccessful privatization left people unemployed and forced to emigrate to bigger economic centers in search for better life. The demographic image of these settlements changed then, since most of the emigrants were young, which caused the appearance of the ageing households. The city area had the identical situation. As long as the economy was good, and affected the fertility rate, the overall number of inhabitants was increasing. With the crash of large industrial facilities, especially "ŠIK KOPAONIK", which was hiring more than 3,000 people in its best years, intense emigration from this area was noted. The only possibility for the young and educated residents for employment is the existence of the enterprise "Planinka" whose business gives hope for survival and prosperity of the municipality. 


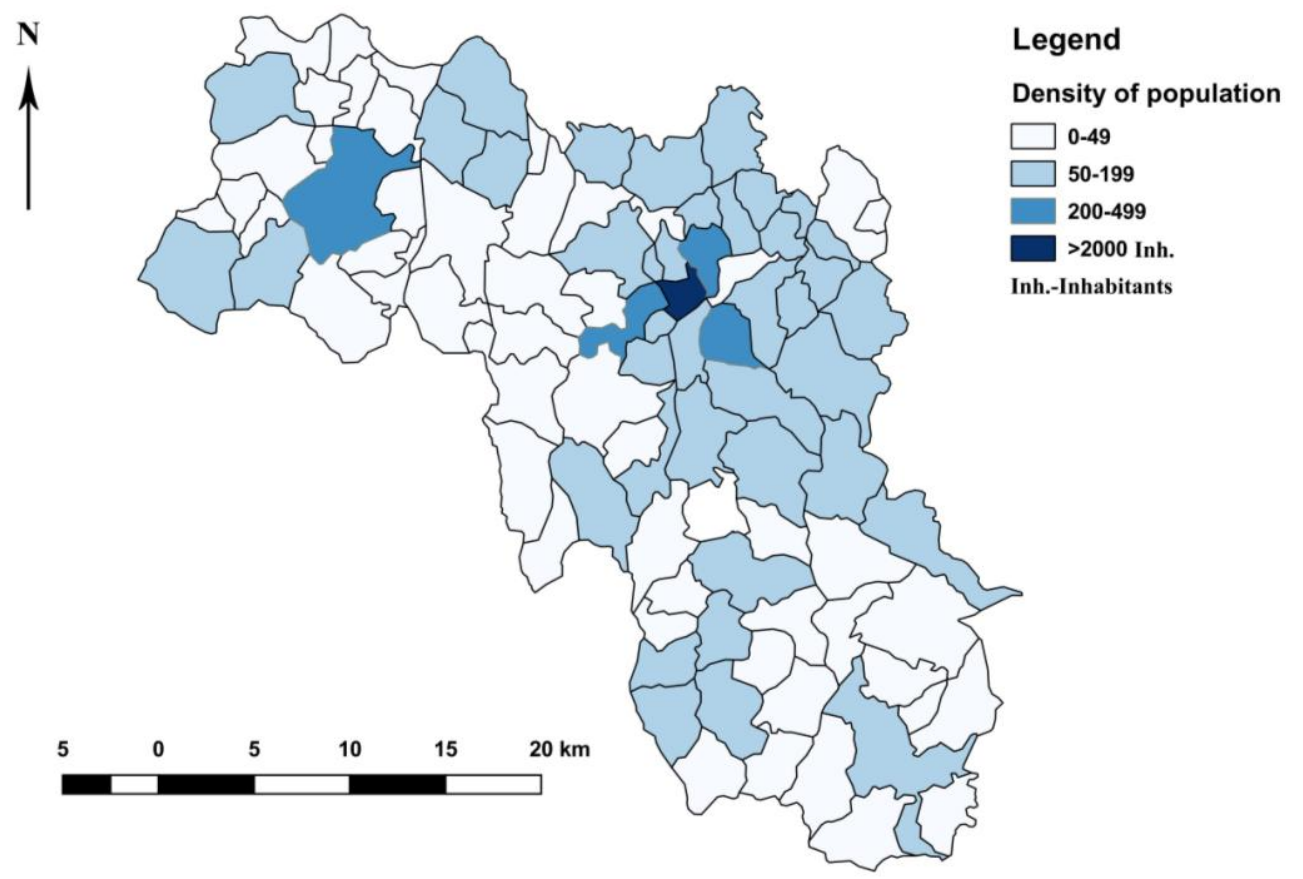

Figure 3. Dispersion and density of population according census of data from 2011 .

\section{Results of the questionnaires}

$51.2 \%$ of the overall number of the questioned residents were women. Most of them were at the age between 20 and 39 $(51,2 \%)$ and most of them were living in a family community. The questionnaire mostly included unemployed people. Out of 127 participants, $11.8 \%$ never started working, $21.3 \%$ had up to two years of service, and $24.4 \%$ had between 2 and 5 years of service, which was at the same time the majority. $7.9 \%$ of the questioned had between 5 and 15 years of service, $21.1 \%$ between 15 and 25 years of service, $7.8 \%$ between 25 and 30 years of service, and only $5.5 \%$ above 30 years. People of different work profiles participated in this questionnaire, from leading positions, highly educated, administrative workers to technical staff and salesmen. Considering the level of their education, $9.4 \%$ of them finished primary education, and $52.8 \%$ had finished high school which was the majority of the questioned. $0.8 \%$ of them were highly qualified, $11.8 \%$ of them higher education, $13.4 \%$ with university degrees, and $6.3 \%$ of them were still studying (Figure 4).

$37.8 \%$ of the questioned were without any income. Most of them $(21.1 \%)$ had monthly income between 15,000 and 25,000 dinars. Almost all the participants stated that it was the first time or the to take part in the questionnaire related to the change of number of municipality residents. Based on the specific questions, $10 \%$ of the participants never thought about leaving their place of residence for the sake of employment or for any other reason, $59.8 \%$ of them never gave up this idea, while $29 \%$ thought about it, but gave up the idea for some other reasons. $51 \%$ of the emigrants left their homes for the sake of employment. Bad economic situation in the municipality and impossibility of employment was the main reason of emigration.
$23.6 \%$ of the questioned stated that they left their homes temporary because of better paid work and for the sake of career advancement. 10 of them noted that their main reason for emigration would be the lack of understanding their environment had shown for their lifestyle.

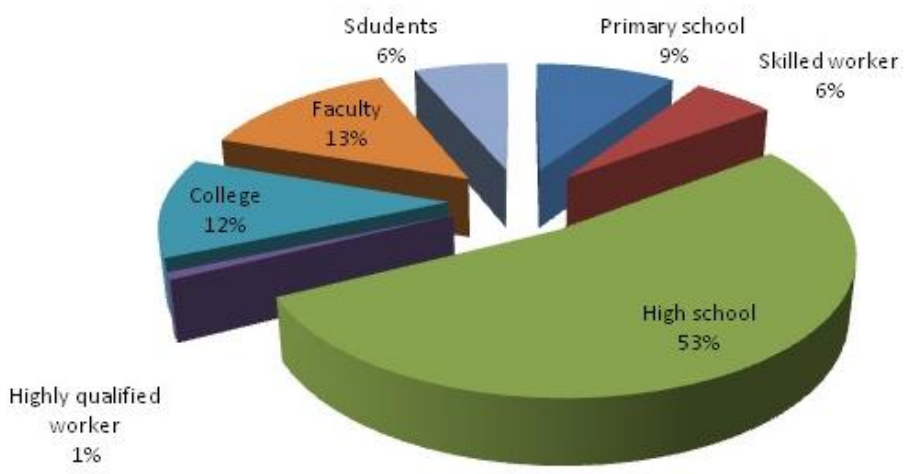

Figure 4. The educational structure of the respondents.

More than half of the questioned $(63 \%)$ were living in their place of residence since their birth, while $33.9 \%$ emigrated from their residence on the territory of the same municipality, mostly villages, during the industrial development of the city. $5.5 \%$ of the questioned named education for the reason of their emigration, $7.9 \%$ emigrated because of economic reasons and impossibility of employment, $9 \%$ emigrated because of the endangered safety, while $15 \%$ emigrated for the sake of marriage. One part of the questioned stated that they visit their former residence, but have no intention of returning in any period. $35.4 \%$ of the participants stated that emigration is completely influenced by the vicinity of administrative border with Kosovo and Metohija, $101 \mathrm{~km}$ long, $46.5 \%$ stated that this 
reason only partially influenced on emigration, while $15 \%$ stated that this reason took no share in the intense emigration from this area. In Kuršumlija, according to the social workers' records, there are 1980 people from Kosovo and Metohija living in the area, 78 of whom are refugees. They have also participated in the questionnaire, and based on the same questions, they confirmed the fact that the main reason for emigration was endangered safety. Figure 5 gives the display of the replies of the participants when asked about satisfaction with the current economic situation in the city. More than a half of them, $53.5 \%$ stated that they are very unsatisfied, $37 \%$ are unsatisfied, and $4.7 \%$ are partially satisfied. 2 of them stated that the economic situation in Kuršumlija is excellent and that they are very satisfied.

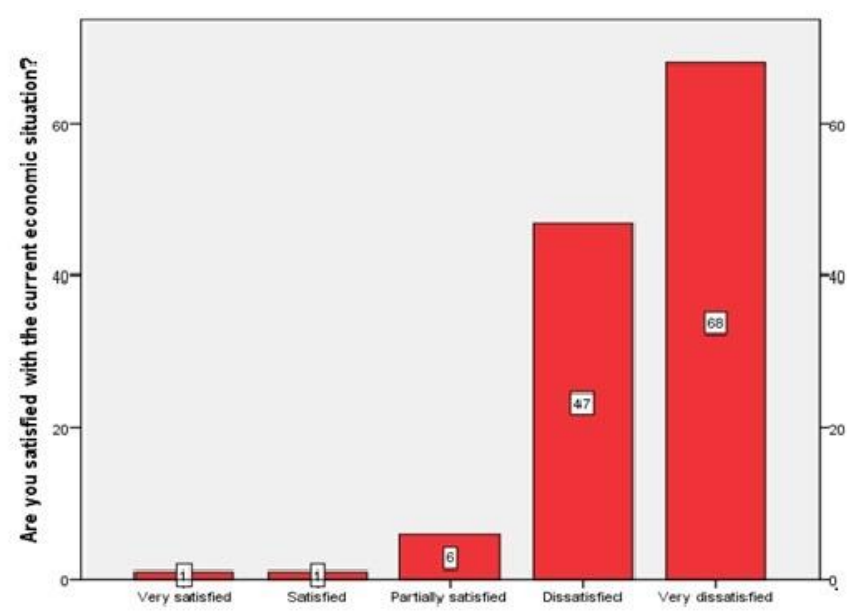

Figure 5.Question from the survey on the current economic situation.

Most of the participants is of opinion that there is a chance for the progress of economy in Kuršumlija, taking into consideration its natural resources and other potentials (Figure 6).

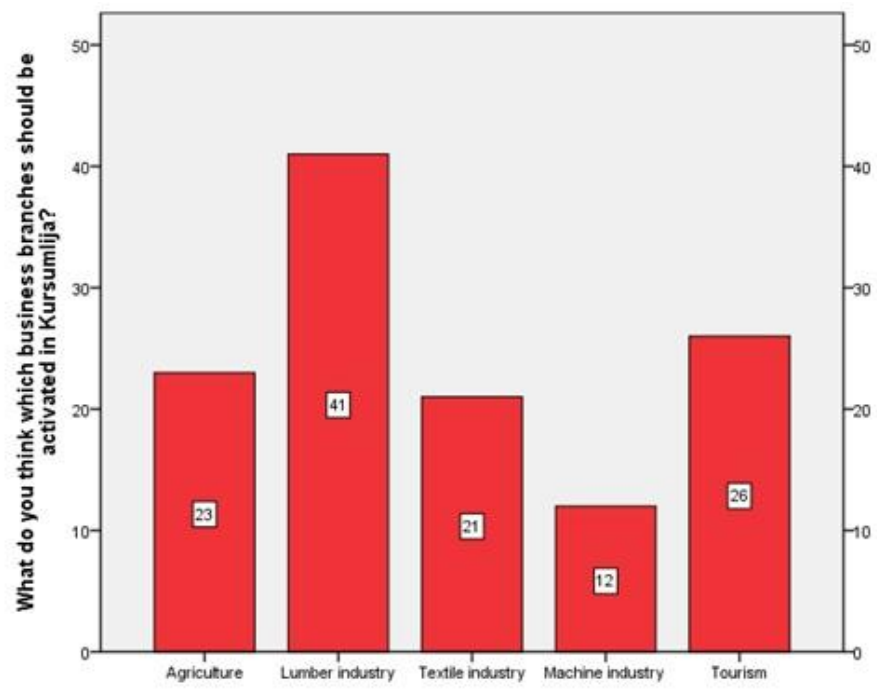

Figure 6. Question from the survey on potential industries to be activated.

\section{Discussion}

Kuršumlija is economically pretty underdeveloped area. Possibilities for employment are very little, and during the last few years inconsiderable. This represents the main reason for emigration from this area. Since most of the population emigrating is at its fertile age, it is no wonder that Kuršumlija is being depopulated. Based on the conducted statistical researches and questionnaires, it has been concluded that the number of inhabitants is at continuous decrease. The only increase of the overall population was caused by sequence of factors, firstly by economic prosperity and high fertility rate in the municipality.

The main consequence of depopulation on the territory of Kuršumlija are bad life conditions in mountain villages, reflected in their seclusion and bad traffic connection, as well as the inexistence of electricity, water supply, inexistence of school, health care, post office, supermarket or any other life necessities (Vukoičić et al., 2011).

Searching for work and better life conditions, inhabitants emigrated to bigger cities, where possibilities for employment were bigger. The decrease of fertility rate is one more reason for the depopulation of settlements. Based on the replies of the questionnaire participants, the vicinity of administrative border with Kosovo and Metohija, which is $101 \mathrm{~km}$ long, has also influenced the emigration. At the very crossing, depopulation is complete. Vukojevac, which is a settlement on the border, had 223 inhabitants in 1948, and according to the last census in 2011, there were no people. Industrialization brought about daily migrations, from the place of residence, mostly villages, to the place of employment. The number of residents on the territory of Kuršumlija mostly diminished in the period between 1981 and 1991 (Statistical office of the Republic of Serbia, 2014). Bad economy of that period also influenced the decrease. Large number of young and able for work emigrated from the municipality because of better life conditions and in search of employment. Temporary work abroad is one more reason for emigration between these two census periods. Based on the questionnaire, it has been concluded that there were many reasons for depopulation and migrations in Kuršumlija, starting with impossibility for employment, as well as the lack of understanding for lifestyle, which was an additional factor for emigration.

SWOT analysis represents a method of displaying positive and negative factors and gives opportunity for influencing them in time. The analysis helps us establish the advantages or strengths and to determine which municipality resources should be used, as well as the disadvantages or flaws. Furthermore, it determines the opportunities and potential threats for the future development of the municipality of Kuršumlija. Based on the SWOT analysis, it can be concluded that the municipality has significant natural potentials and resources at its disposal, which can contribute significantly to the progress. Good geographical position and the existence of a busy motorway E- 80 should be 
used properly. The construction of the highway from Niš to Priština is planned on the same direction, which will further promote the existing municipality's potential. Good traffic position can additionally contribute to the attracting of a large number of investors. Healthy environment without big industrial polluters represents a base for the development of ecological branches of economy and new branches of tourism (country, eco, winter, hunting, transit etc.) Special attention should be paid to the usage of renewable energy sources. "The Toplica region gives an excellent opportunity for the construction of solar panels and solar farms. This region as well as the whole southeast Serbia have good chances for new renewable sources of energy“ (Valjarević, 2016)
Additional valorization of touristic potentials, as well as the enforcement of Kuršumlijska spa, which has been one of the most famous spas in Serbia for years, is only one of many advantages to be used. Opening of health care units in remote rural areas would stop the drain of population to some extent, and it should be given special attention. Enforcement of country tourism is also one of the advantages which require attention. "Country tourism is a way of revitalizing many rural areas, even those completely depopulated, and it is certainly the way to stop the emigration of young people, because it presupposes the creating of common conditions and higher standards of comfort in rural areas" (Vukoičić et al., 2016).

\section{SWOT - analysis}

\begin{tabular}{|c|c|}
\hline Strengths & Flaws \\
\hline $\begin{array}{l}\text { - Peace in the region } \\
\text { - Good geographical position } \\
\text { - traffic position on an important motorway E-80, part } \\
\text { Niš-Priština, as well as the planned construction of the } \\
\text { highway } \\
\text { - Existence of three spas (Kuršumlijska, Prolom, } \\
\text { Lukovska), } \\
\text { - Existence of the natural phenomenon and natural } \\
\text { monument "Devil's city", } \\
\text { - Good natural conditions (forests, waters, mines, } \\
\text { geothermal and mineral waters, flora and fauna), } \\
\text { - Possibilities for the application of sustainable energy } \\
\text { sources (small hydroelectric power plants and sun } \\
\text { collectors) } \\
\text { - Rich cultural and historical heritage especially from the } \\
\text { medieval period, (monasteries from the period of } \\
\text { Nemanjići dinasty, from the } 12^{\text {th }} \text { century, St. Nicholas and } \\
\text { Virgin Mary) } \\
\text { - Healthy environment without industrial polluters } \\
\text { - Great possibilities for the development of eco-agriculture } \\
\text { - Tradition and customs } \\
\text { - Hospitality } \\
\text { - Development of forestry, hunting industry, and } \\
\text { woodworking } \\
\text { - Significant possibilities for the development of new } \\
\text { branches of tourism (country, eco, winter, hunting, transit } \\
\text { and juvenile) } \\
\text { - Low prices of products and services }\end{array}$ & $\begin{array}{l}\text { - Political instability } \\
\text { - Dormancy of numerous natural advantages (forests, } \\
\text { tourism, hunting and fishing possibilities), } \\
\text { - Unfavorable demographic status of the municipality, } \\
\text { especially in the villages), } \\
\text { - Negative fertility rate and migration of the fertile } \\
\text { residents, which leads to depopulation and intense ageing } \\
\text { of population, } \\
\text { - Bad traffic connection within the municipality, } \\
\text { especially between rural areas } \\
\text { - Extinction of large number of villages and whole parts } \\
\text { of the municipality, especially at the administrative } \\
\text { border with Kosovo, } \\
\text { - Low industrial activity and extinction of old industrial } \\
\text { branches, } \\
\text { - Lack of documentation } \\
\text { - Bad infrastructural equipment of greater part of } \\
\text { municipality, even important villages , } \\
\text { - Weak touristic offer, in the area of culture and services } \\
\text { - Medieval cultural heritage is not properly included into } \\
\text { touristic offer } \\
\text { - Underqualified staff, } \\
\text { - Low socio-economic status of population } \\
\text { - Insecurity of new investments, } \\
\text { - Disinterest for the reconstruction of village facilities } \\
\text { which could be used for touristic purpose and promotion } \\
\text { of country tourism } \\
\text { - Vicinity of the administrative border with Kosovo and } \\
\text { Metohija }\end{array}$ \\
\hline Opportunities & \begin{tabular}{|c|} 
Threats \\
\end{tabular} \\
\hline $\begin{array}{l}\text { - Recognition of the municipality on the Republican level, } \\
\text { especially its touristic destinations } \\
\text { - Higher level support ( ministries and authorized public } \\
\text { organizational, NGOs, foreign organizations for support } \\
\text { and help) } \\
\text { - Government support and support of the National } \\
\text { directorate of employment in a way of providing } \\
\text { subvention and non-refundable loans for self-employment, } \\
\text { - Branding of agricultural products and their distribution on } \\
\text { Serbian and European market } \\
\text { - Recognition of spas and spa tourism as important for the } \\
\text { development and promotion of Serbia, }\end{array}$ & $\begin{array}{l}\text { - The position of the municipality in South Serbia, as the } \\
\text { most underdeveloped and under populated part of the } \\
\text { Republic } \\
\text { - Politics domination over expertise } \\
\text { - Dependence of the future development of the } \\
\text { municipality on higher instances (state, region, } \\
\text { international funds), } \\
\text { - Bad connection and cooperation with surrounding } \\
\text { municipalities in the South, the West and the East } \\
\text { - Long administrative border with Kosovo } \\
\text { - Unstable political situation in the environment, } \\
\text { - Uncontrolled exploitation of forests, }\end{array}$ \\
\hline
\end{tabular}




\begin{tabular}{|c|c|}
\hline $\begin{array}{l}\text { - the existence of the program of cooperation and support } \\
\text { from the state for the municipalities of South Serbia, } \\
\text { - Inclusion of spas and locality “Devil's City" into } \\
\text { developmental measures of the Republic, and inclusion of } \\
\text { the region into appropriate plans and strategies } \\
\text { - Possibilities for promotion of cooperation with } \\
\text { surrounding municipalities } \\
\text { - State highway Niš-Priština as a skeleton of further } \\
\text { development of this part of Serbia }\end{array}$ & $\begin{array}{l}\text { - Inability to attract educated and qualified work force } \\
\text { from the surrounding area as a way of faster, future } \\
\text { development, } \\
\text { - More frequent migrations of young, highly educated } \\
\text { inhabitants towards bigger economic centers. }\end{array}$ \\
\hline
\end{tabular}

\section{CONCLUSION}

Based on the conducted statistical and field researches, it has been concluded that the last decades of the $20^{\text {th }}$ and the beginning of the $21^{\text {st }}$ century were marked by prominent demographic changes, manifested through depopulation and intense ageing of the inhabitants. The main reasons for the structural changes and the decrease of overall population and depopulation are prominent emigration, fertility, economic, social and other factors. Taking it all into account, appropriate measures, regarding the population policy, should be taken to diminish the drain of population from this area. The only way to diminish the emigration is to revitalize once large industrial facilities, especially forest industry. Investing in agriculture and processing industry, and development of industrial branches based on existing natural resources and opening small family businesses will greatly decrease the emigration of population. Additional valorization of current touristic potentials, especially investing into rural tourism for whose development there are extraordinary conditions, would also diminish the drain of young and able for work from rural environments and cities. Negative demographic trends have been placing Kuršumlija and the Toplica region into areas with prominent depopulation for years, which had negative consequences for economic and social progress.

\section{REFERENCES}

Bakić R. 1977. Opšta demografija. Priština: Prirodnomatematički fakultet u Prištini.

Blagojević, V., \& Milosavljević, B. 2016. Političko-pravni okvir savremenih migracija u Jugoistočnoj Evropi. Vojno delo, Institut za strategijska istraživanja, 3/2016, pp. 75-93.

Comparative Review 2014. Census of Population, Households and Flats in 2011. Comparative Review, No. 20, Belgrade.

Grćić, M. 2010. Demografske posledice ratnih gubitaka. Demografija. Geografski fakultet u Beogradu, Beograd.

Heleniak, T. 2015. Changes in the population in the former communist countries of Europe and Asia. In International Encyclopedia of Social and Vedic Science.

Maksimović, M. 1996. Hronika Kosanice. Kuršumlija: Opštinski odbor Kuršumlije.
Official Gazette of the Republic of Serbia 2012. Law on Migration Management. Official Gazette of the Republic of Serbia, No. 107/2012.

Population census, Comparative overview of the number of households, data by settlements 2012. Belgrade. Book 10 .

Republic Statistical Office of the Republic of Serbia. Census of Population, Households and Flats in 2011.

Rudić, V. 1978. Stanovništvo Toplice. Beograd: Srpska akademija nauka i umetnosti - Etnografski institut. posebna izdanja, knjiga 17.

Valjarević, A., Đekić, T., Stevanović, V., Ivanović, R., \& Jandziković, B. 2018. GIS numerical and remote sensing analyses of forest changes in the Toplica region for the period of 1953-2013. Applied Geography, 92, pp. 131-139. doi:10.1016/j.apgeog.2018.01.016

Valjarević, A. 2016. GIS modelling of solar potential in Toplica region. The University Thought - Publication in Natural Sciences, 6(1), pp. 44-48. doi:10.5937/univtho6-10739

Vukoičić, D., Punišić, M., \& Nikolić, M. 2011. Demographic changes and processes in the network of settlements of the municipality of Kuršumlija. Geographical research, No. 3. Faculty of Natural Sciences and Mathematics, Department of Geography, Kosovska Mitrovica.

Vukoičić, D., \& Nikolić, M. 2013. Promene broja stanovnika, domaćinstava i gustine naseljenosti u Topličkom okrugu u drugoj polovini XX i početkom XXI veka. Demografija, knj. $\mathrm{X}$, Međunarodni časopis za demografska i ostala društvena istraživanja. Univerzitet u Beogradu, Geografski fakultet Institut za demografiju, Beograd, ISSN 1820-4244.

Vukoičić, D. 2014. Tourist valorization of urban, spa and rural settlements Gornje Toplice. Kosovska Mitrovica: University of Prishtina with temporary headquarters in Kosovska Mitrovica - Accessory - Faculty of Mathematics.

Vukoičić, D., Nikolić, M., \& Raičević, J. 2017. Rural Tourism As The Concept Of Sustainable Economic Development of the Kursumlija Municipalitu. In 4th International Scientific Conference Agribusiness MAK-2017 „EUROPEAN ROAD“ IPARD 2015-2020, 2017, Kopaonik, Serbia. pp. 123-134.

Vukoičić, D., Nikolić, M., \& Raičević, J. 2016. Contemporary demographic changes in settlements along the administrative line in Serbia towards autonomous province of Kosovo and Metohija. The University Thought - Publication in Natural Sciences, 6(2), pp. 17-26. doi:10.5937/univtho6-12758 